\title{
Carbon in the Coastal Seascape: How Interactions Between Mangrove Forests, Seagrass Meadows and Tidal Marshes Influence Carbon Storage
}

\author{
M. Huxham ${ }^{1}$ - D. Whitlock ${ }^{2}$ M. Githaiga ${ }^{3}$ - A. Dencer-Brown ${ }^{4}$
}

Published online: 28 April 2018

(C) The Author(s) 2018

\begin{abstract}
Purpose of Review We use the 'seascape' concept to explore how interactions between mangrove forests, tidal marshes and seagrass influence the storage of carbon in these ecosystems. Mangrove forests, with the other two 'blue carbon' habitats, are exceptionally powerful carbon sinks. Maintaining and enhancing these sinks is an emerging priority in climate change mitigation. However, managing any one ecosystem on its own risks is ignoring important contextual drivers of carbon storage emerging from its place in the seascape. We consider how interactions between these coastal habitats directly or indirectly affect the amounts of carbon they can store.

Recent Findings The export of carbon from seagrasses may occur over hundreds or thousands of kilometres, much further than reported for mangroves or tidal marshes. Seagrasses may buffer mangroves from wave impacts, assisting forest regeneration. Trophic cascades supported by contiguous blue carbon habitat may limit excessive herbivory and bioturbation in them but evidence is limited.

Summary Direct transfers of carbon between blue carbon habitats are common and are likely to enhance total carbon storage, but our understanding of their contribution to carbon stocks at the seascape level is elementary. There is evidence for indirect enhancement of carbon storage at the seascape by close association of habitats, mostly through the creation and maintenance of propitious conditions by one ecosystem for another. Protection from waves of mangroves by seagrass and protection from excess nutrients and sediment of seagrass by mangroves and tidal marsh are key mechanisms. There is little evidence or theory suggesting negative effects on carbon storage of one blue carbon habitat on another.
\end{abstract}

Keywords Mangrove $\cdot$ Seagrass $\cdot$ Tidal marsh $\cdot$ Carbon $\cdot$ Seascape $\cdot$ Sequestration

My first summer in the Sierra, 1911, The Riverside Press Club, Cambridge, USA

This article is part of the Topical Collection on Physiological Processes

\section{Huxham}

M.huxham@napier.ac.uk

1 School of Applied Sciences, Edinburgh Napier University, Sighthill Campus, Edinburgh EH11 4BN, UK

2 School of Life Sciences, Edinburgh Napier University, Edinburgh, UK

3 Department of Biological Sciences, University of Embu, Embu, Kenya

4 Institute for Applied Ecology, Auckland University of Technology, Auckland, New Zealand
'When we try to pick out anything by itself, we find it hitched to everything else in the Universe' (John Muir)

\section{Introduction}

Mangroves are unusual forests. Their remarkable abilities to thrive in saline, intertidal, oxygen-depleted soils restrict them to a narrow coastal niche making them globally rare. Their location at the interface of land and sea makes them nodes and conduits in ecological networks, with cross-boundary flows of energy, materials, and organisms greater than other forests. Mangrove forests, along with tidal marshes and seagrass meadows, are the vegetated coastal habitats known as 'blue carbon' ecosystems. Despite covering only around 3\% of the area occupied by forests on land, these systems annually bury 
a similar amount of organic carbon, and they are amongst the most powerful carbon sinks on the planet [ $1 \bullet$. Carbon in these wetland soils may be buried for millennia in sinks that do not reach saturation and, unlike freshwater systems, generally do not generate much methane (although there are exceptions [2]). For these reasons, there is growing interest in managing, protecting, and restoring blue carbon habitats as part of local and global climate change mitigation policies [3].

All ecosystems are open to exchanges of energy, materials and organisms, and delineating their boundaries is difficult. Indeed, ontological debates around defining what is meant by the term 'ecosystem' and practical difficulties in justifying the limits of particular examples have characterised ecological science from its inception. These problems are particularly acute - but also particularly instructive - for blue carbon habitats. This is because they are liminal by their nature; a mangrove forest has marine and terrestrial features; it may benefit from flows of water, sediments and nutrients coming from hundreds of miles inland and might nurture fish destined to spawn miles offshore. Hence a landscape - or rather 'seascape'-perspective is essential in understanding many ecological functions in these habitats. This approach is becoming influential in the literature on tropical coastal fisheries, where a focus on the mosaic of inter-connected habitats, used by fish species at different points in the tide and in their life-cycles, can bring rich understanding $[4,5]$. Here, we explore how such a seascape perspective, looking at links between blue carbon ecosystems, may inform our knowledge of carbon capture and storage in them. Most of our paper considers the documented or likely positive effects of one of these ecosystems on carbon capture or storage in another but we also consider evidence for negative interactions.

The exceptional carbon density found in these vegetated coastal habitats arises from four shared features. First, they are generally highly productive; indeed, they rank amongst the most productive of all ecosystems. Despite growing in apparently stressful environments, mangroves show productivity similar to terrestrial tropical forests; the mean aboveground net primary productivity is $1113 \mathrm{~g} \mathrm{DW} \mathrm{m}^{2}$ year $^{-1}$, but note that belowground productivity probably exceeds that typical for terrestrial forests [6]. Seagrasses have mean productivity of $1012 \mathrm{~g} \mathrm{DW} \mathrm{m}^{2}$ year $^{-1}$ [7]. Tidal marshes often exceed these values. With some older estimates of up to $8000 \mathrm{~g} \mathrm{DW} \mathrm{m}^{2}$ year $^{-1}$ and a more recent range, for temperate marshes, of up to $3990 \mathrm{~g} \mathrm{DW} \mathrm{m}^{2}$ year $^{-1}$ (but with a large variation driven by climatic, edaphic and tidal differences) [7 p101], they may be the most productive of any recorded natural ecosystem. For both mangroves and tidal marshes, high productivity sites are those with, all else being equal, large tidal ranges and therefore copious and regular flows of tidal water. This high productivity results in large amounts of, often refractory, autochthonous material. Second, they are able to trap allochthonous material, as water moves through a dense maze of stems, fronds or above-ground roots. For example, around half of the organic carbon found in seagrass beds is typically imported from elsewhere [8]. Third, blue carbon vegetation grows in permanently wet soil with typically very low levels of oxygen. This means decomposition of buried carbon is slow, a characteristic encouraged by typically high C:N ratios found in blue carbon litter. Fourth, it seems that most blue carbon sinks do not reach saturation and can respond to rising sea level through surface elevation facilitated, in part, through the storage of carbon [9••]. Habitat links influencing carbon capture and storage will therefore be those that influence these characteristics: productivity, the ability to trap carbon and the ability to store it without rapid oxidation. Here, we consider 'carbon storage' to refer to the long-term integrated balance between processes of carbon accumulation (through for example the accretion of carbon rich sediment) and carbon loss (through for example the oxidation of organic carbon in soils and subsequent release of $\mathrm{CO}_{2}$, into water or the atmosphere). We review mechanisms that may change rates of carbon capture, or carbon loss or both.

Based on measurements of rates of destruction of blue carbon habitats, along with typical carbon densities in them, Pendleton and colleagues estimated that between 0.15 and $1.02 \mathrm{Pg}$ carbon is being lost from coastal vegetated habitats annually [10]. Lovelock et al. review the conditions under which stored carbon may be at risk of re-oxidation. They highlight the dangers of physical disturbance to soils but also changes in bioturbation [11]. Here, we consider how habitat links may influence these processes. Previous work has summarised a range of positive interactions between mangroves, seagrass and coral reefs [12•.0]; some of these- specifically effects on wave heights, nutrient exchanges and sediment trapping - have implications for carbon capture and storage and so are further explored here. In addition, we consider how one blue carbon habitat may provide 'subsidies' of carbon for another, an extension of the original 'outwelling' hypothesis. Hence, we review the literature for evidence of five mechanisms by which blue carbon habitats may affect carbon sequestration and storage in adjacent ones: one direct mechanism - outwelling - and four indirect ones - wave damping, sediment transport, nutrient exchange and trophic cascades (Fig. 1).

\section{Direct Transfers of Carbon}

\section{Out and Inwelling}

The 'outwelling hypothesis' originated in work on Atlantic North American coasts, which suggested that secondary production in adjacent coastal waters was supported by carbon transferred from tidal marshes, in which up to $50 \%$ of productivity was surplus to autochthonous consumption or storage [13]. The idea was expanded to include mangrove forests and 


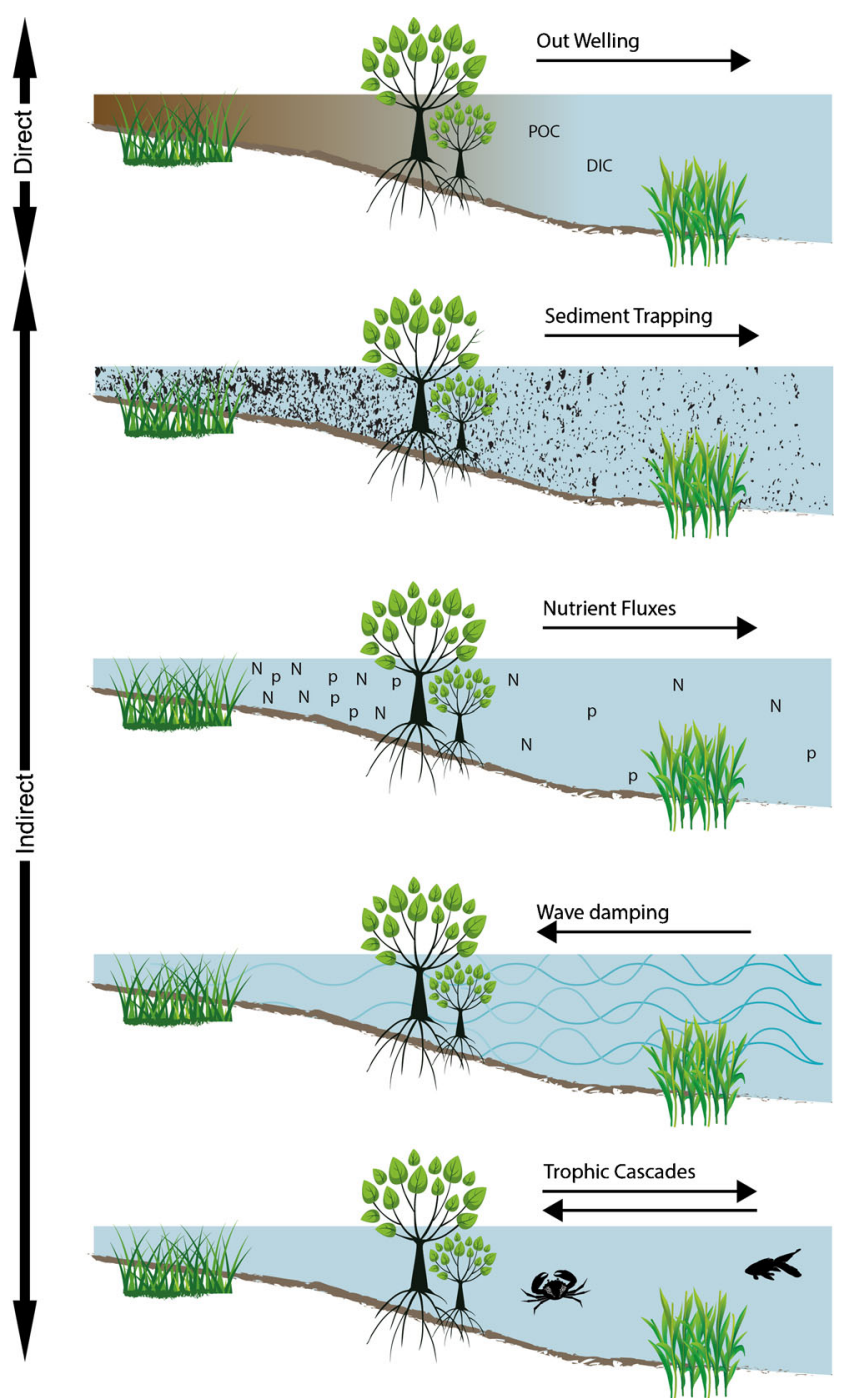

Fig. 1 Direct and indirect mechanisms by which one blue carbon habitat may influence the carbon concentration and future sequestration in adjacent blue carbon habitats. From the top, by direct transfers of carbon (outwelling or inwelling), by protecting adjacent habitats from excess nutrients, sediments or wave energy and through the trophic control of bioturbation and herbivory

was promoted from 'theory' to 'paradigm' by Odum and other originating authors $[14,15]$. It dominated early understandings of carbon movement between coastal habitats, inspired much of the subsequent work and remains influential today. However, it is now clear that outwelling is far from paradigmatic, but rather is heavily dependent on biological and geomorphological settings; in some systems, there is substantial movement of carbon offshore; in others, little; and in some, there is inwelling of material from deeper to shallower habitats. Here, our focus is restricted to carbon capture and storage - specifically to whether the co-occurrence of blue carbon habitats is likely to result in the storage of larger quantities of carbon than when these habitats occur alone. Hence, we do not address the original concern of the outwelling hypothesis, which was the idea that inshore productivity supported consumption offshore. Nor do we consider 'trophic relays' or ontogenetic migration, in which movements of organisms indirectly transfer carbon [16], since these are unlikely to result in carbon storage.

Outwelling from Mangroves to Seagrass Indirect evidence for the existence of outwelling from mangroves comes from the discrepancy between estimates of the total mangrove sink and those of total mangrove productivity, with more than half of carbon fixed by mangroves (112-160 $\mathrm{Tg}$ year $^{-1}$ ) unaccounted for [17]. This carbon could be exported as litter, as particulate organic carbon (POC), as dissolved organic carbon (DOC) or as dissolved inorganic carbon (DIC). The latter was found to be very important at an Australian site [18]; if this result applies elsewhere, it would imply a reduced potential for mangroves to enhance carbon storage offshore, since DIC is unlikely to be sequestered (although some authors describe DIC in the deep ocean as a carbon sink, since exchange times with the atmosphere are in the hundreds to thousands of years). However, a global review did conclude that mangroves, on average, are indeed sources of litter and POC, with mean export offshore of $202 \mathrm{~g} \mathrm{C} \mathrm{m}^{2}$ year $^{-1}$ [19]. Carbon subsidies from mangroves were correlated with higher temperatures and lower rainfall. Most studies suggest that transport of this material is limited to within one or at most a few kilometres of the coast. For example, Hemminga et al. [20] and Chen et al. [21] explored export of mangrove material at two different sites; Gazi Bay, Kenya and North Sulawesi, Indonesia, respectively. They found rapid declines in mangrove carbon with distance from the forest and no mangrove derived material $3 \mathrm{~km}$ from the source. Seagrasses are efficient traps for detritus and POC [22-24], and on average $\sim 50 \%$ of carbon buried within seagrass beds is autochthonous [8]. Where seagrasses are adjacent to mangroves, large proportions and amounts of carbon buried in the seagrass beds can originate from the forests. For example, Kennedy and colleagues explored 15 coastal locations in the Phillippines and Vietnam where seagrass meadows were located in close proximity to mangrove beds, and found that mangrove derived carbon was the dominant carbon source within the sediment [25]. Chen and colleagues [21] found that up to $83 \%$ of the organic carbon buried in seagrass soil at their sites in Indonesia was derived from mangroves. Hence, the general pattern is that, where seagrasses are close to mangroves, they will bury carbon derived from those forests. This suggests that total carbon storage in seagrass habitats is enhanced by proximity to mangroves, an inference supported by the greater historical rates of carbon burial found at a Mexican site in seagrass next to mangroves compared to that further away [26]. However, the data to assess this are sparse and some are contradictory. The only study to look specifically at landscape level effects, including mangrove proximity, on $\mathrm{C}_{\text {org }}$ storage in tropical seagrasses at nine sites found that the area of contiguous mangrove was negatively 
related to soil carbon in the seagrass. However the authors suggest this could be related to (and thus confounded by) fragmentation of seagrass beds, with sampling sites in larger more continuous meadows having higher $\mathrm{C}_{\text {org }}$ concentrations [27•]. The total capture of carbon at a seascape level might be higher when mangroves and seagrasses occur together, even if $\mathrm{C}_{\text {org }}$ is lower in seagrasses, since mangroves may intercept and trap terrigenous carbon some of which would otherwise be found in seagrass. Hence, given that many or most mangroves show high productivity and outwelling of carbon, and that seagrasses are highly efficient traps for authocthonous carbon, it remains likely that seagrass carbon is enhanced by proximity to mangroves, particularly through enhanced rates of accretion of allochthonous carbon. However, our understanding of the nuances of this relationship and how seascape configurations might affect, it is at an early stage. A recent contribution from a temperate setting, that shows some of the potential complications, demonstrated that much of the new trapped carbon in a tidal marsh was in fact 'old' allochthonous material coming from elsewhere, that may have been deposited and stored in a different place had it not been trapped in the marsh [28].

Outwelling from Tidal Marshes Tidal marshes were the originating ecosystem for the outwelling hypothesis. Despite this, an early analysis of sources and fates of marine autotrophic production suggested they were likely to export less $(19 \%$ NPP) than the other blue carbon habitats (24 and $30 \%$ of NPP for seagrass and mangroves, respectively) [29]. Work since then has tended to support this, with their high tidal position also limiting the movement of litter and POC. Although work in Chesapeake Bay, USA, reported signatures of tidal marsh carbon up to $1 \mathrm{~km}$ from its source [30], movement of marsh carbon is usually reported to be more limited. For example, carbon exchanges across a tidal marsh/ mangrove boundary in Australia were restricted to a few metres [31]. We found no evidence for the enrichment of adjacent mangrove or seagrass beds with tidal marsh carbon.

Inwelling from Seagrass On average, $24 \%$ of seagrass productivity is exported beyond seagrass meadows; some of this may travel hundreds or even thousands of kilometres and contribute to carbon sequestration in the deep sea [32॰]. A growing body of work demonstrates the potential, at least at some sites and under some conditions, for the transfer of carbon from seagrass to inshore habitats, particularly mangroves. Bouillon and Connolly [16] show pictures of seagrass litter accumulated within mangroves and cite three studies documenting direct and indirect evidence for carbon flows from seagrass to mangroves. Walton et al. examined the inwelling of material from seagrass beds to mangrove forests in Qatar, and concluded that in this arid system, these subsidies were important in sustaining the forests; however, this was due to flows of nitrogen rather than carbon [33]. Hence, seagrass carbon certainly moves to, and may accumulate in, other blue carbon habitats; although, there is no work that estimates the possible extent of this.

\section{Indirect Impacts on Carbon Storage}

\section{Wave Damping}

The movements of water-as currents, tides, eddies and waves - write the story of the coast. By changing those movements, vegetated coastal habitats alter the plot. Vegetation slows water movement down, attenuates wave energy and encourages deposition, rather than erosion, of sediments. The coastal protection function of blue carbon habitats emerges from two types of effect: these ecosystems can elevate soil surfaces, reducing total water depth and thus encouraging wave breaking, and they also dissipate energy through increased friction, between the water and the surfaces over which it flows and increased turbulence by changing flow [1•]. These effects are manifest with surprisingly little vegetation. For example, small patches of the seagrass Zostera noltii, consisting of thin and flexible fronds of only $18 \mathrm{~cm}$ length, have significant effects on coastal erosion on a Scottish shore [24]. Vegetation that is lush and dense, such as tropical mangrove forests that may exceed $30 \mathrm{~m}$ in canopy height and $500 \mathrm{tha}^{-1}$ biomass, transforms water movements. The energy of even major storm surges or tsunami waves exceeding $10 \mathrm{~m}$ in height will be reduced or dissipated by sufficiently dense mangrove forest [34].

Habitats acting together are more effective in providing coastal protection services than those on their own [35•]. Mangroves and tidal marshes both rely on calm conditions for recruitment of seedlings at their seaward fringes. Gillis and colleagues reviewed the literature for a threshold wave height beyond which mangroves will not 'establish or persist', and found a value of $0.5 \mathrm{~m}[12 \bullet \cdot]$. 'Windows of opportunity', during which wave and tidal movements are unusually low, allow small plants to establish sufficient root length to withstand scouring [36]. Without these windows, and if waves persist above this threshold, then recruitment can fail, leaving mature habitats unable to regenerate and eventually susceptible to degradation and decline. For example, following removal of some of the trees wave scour has prevented regeneration in a mangrove fringe forest in Kenya for over 40 years [37]. Because seagrass and mangroves reduce wave energy, it is likely that they act to allow persistence, regeneration and expansion of contiguous, inshore blue carbon habitats. For example, modelling the impacts of seagrass on wave height and bed shear stress on a mangrove shore found that conditions typical of a Belizean lagoon could reduce shear stress below the threshold for sediment movement under non-storm conditions [35•]. Even during storms, these simulations 
suggested a significant protective effect of seagrass on mangroves, with the former reducing the volume of mud scoured from the mangrove forest floor by $1 \mathrm{~m}^{3} \mathrm{~m}^{-1}$. This protective effect will depend on a range of physical and biological variables. Higher standing biomass, greater plant stiffness and year-round, rather than seasonal, verdancy will make seagrass more effective [38], hence tropical seagrass meadows are likely to exercise a greater protective effect (on mangroves and tropical salt marshes) than temperate ones (on temperate salt marshes)

The theoretical case for seagrass habitat protecting and facilitating the establishment and persistence of mangroves, at least in some settings, is therefore strong. This argument implies greater total carbon storage, since without these protective effects, mangrove forests may fail to regenerate or to expand spatially, and therefore could lose their abilities to continue to sequester carbon as well as begin releasing previously stored sedimentary $\mathrm{C}_{\text {org }}$. A similar case can be made for positive links between seagrass and tidal marsh. However, this is less compelling given the higher tidal location of tidal marshes and the smaller biomass typical of temperate seagrass (in the tropics, marshes are likely to be contiguous with mangroves). Despite this theoretical feasibility, the empirical evidence is indirect. We could find no examples where loss of seagrass has been shown to result in mangrove or tidal marsh loss or degradation (and therefore loss of carbon). The lack of such evidence is perhaps unsurprising, given the large spatial and temporal scales that may be involved, but this suggests an interesting opportunity for new research.

\section{Sediment Transport}

All blue carbon habitats trap sediment. This accretion plays important ecological roles; it may bring in limiting nutrients [39], assist coastal habitats in adjusting to sea level rise [9•] and constitute an important route by which carbon is captured and sequestered [8]. However, excessive sediment flows can cause problems. Whilst very large and sudden dumps of sediment may kill tidal marshes and mangroves (e.g. following El Nino flooding in Kenya: [40]) these systems are usually highly resilient in the face of sediment deposition and indeed benefit from it. In contrast, seagrass meadows are sensitive because of their reliance on high levels of insolation and consequent vulnerability to increases in turbidity. For example monitoring sites in Sabah, Malaysia, lost most of their seagrass over a 5-year period as turbidity levels increased with concomitant falls in light intensity [41]. Sediment can accumulate in mangroves and tidal marshes over millennia. The terrigenous contribution in most forests and marshes can be demonstrated using numerous markers, including those linked closely to human activity. For example, phosphorus and copper washed from agricultural catchments [42] and PCBs from industrial areas [43] have been found in mangrove cores containing sediments originating from inland. The ability to trap sediments (and therefore to sequester carbon) is compromised if these habitats are degraded or removed. Case studies and modelling show how near-shore turbidity levels, distribution of fine sediments and sedimentation rates may change following mangrove removal [44-46]. Sediment trapping by mangroves can help protect sensitive coral sites from soil runoff [47], and similar effects are likely for seagrass; indeed, the enhanced sedimentation that destroyed the seagrass beds in Sabah [41] was caused by removal of forests, including neighbouring mangroves. Hence, landward blue carbon habitats are likely to protect seagrass from excessive sediment and turbidity at multiple sites, contributing to on-going carbon sequestration and storage within those seagrass beds by maintaining the conditions under which they can flourish.

\section{Nutrient Fluxes}

Nitrogen and phosphorus are limiting nutrients in most blue carbon ecosystems, and adding them in small amounts usually stimulates growth $[6,48]$. However, human activities have amplified natural $\mathrm{N}$ and $\mathrm{P}$ cycles by $\sim 100$ and $\sim 400 \%$ respectively, massively increasing their availability across the globe [48, 49]. Detrimental effects of excessive nutrients, such as altered nutrient soil ratios, vegetation damage, increased soil acidity and eutrophication, are now common in coastal systems [49]. Whilst excess nitrogen can lead to mangrove damage and mortality [50] and disruption or degradation of tidal marsh communities [51], seagrasses are the most vulnerable of the blue carbon habitats. Enhanced nitrogen can reduce seagrass production and coverage [52, 53], and eutrophication is recognised as a key threat to seagrasses globally [54]. Gillis and colleagues give threshold values of $\mathrm{N}$ and $\mathrm{P}$, below which seagrasses can establish and persist, of 0.04 and $0.002 \mathrm{~g} \mathrm{~m}^{2} \mathrm{day}^{-1}$; these compare with 0.07 and 0.04 for mangroves [12••].

Tidal marshes and mangroves have high rates of nitrogen burial and denitrification [52]. Because plant production and carbon storage capacity of tidal marshes and mangroves are often limited by nitrogen availability [55-58], both ecosystems have the potential to act as nitrogen sinks. Since carbon fixation and subsequent mineralisation are linked to nitrogen availability, and denitrification is influenced by the supply of labile carbon, the carbon and nitrogen cycles in coastal ecosystems are closely coupled [59]. Increased nitrogen deposition is enhancing carbon storage in the world's terrestrial forest biomass by up to $0.31 \mathrm{Pg}$ carbon per year [60]. Carbon sequestration in mangroves may also be enhanced under nitrogen enrichment [61]. Here, we consider the evidence for how blue carbon habitats may influence the ability of adjacent ecosystems to continue to sequester and store carbon through their influence on nitrogen (and to a lesser extent, phosphorus) flows. Results are summarised in Fig. 2. 
Fig. 2 Nutrient (nitrogen and phosphorous) fluxes or changes mediated by invasions, between the blue carbon habitats of salt
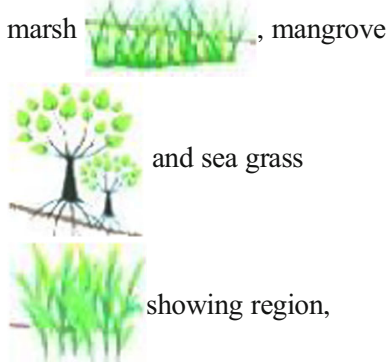

effect type: positive ??, negative ? or neutral $\square$, direction of flux and references

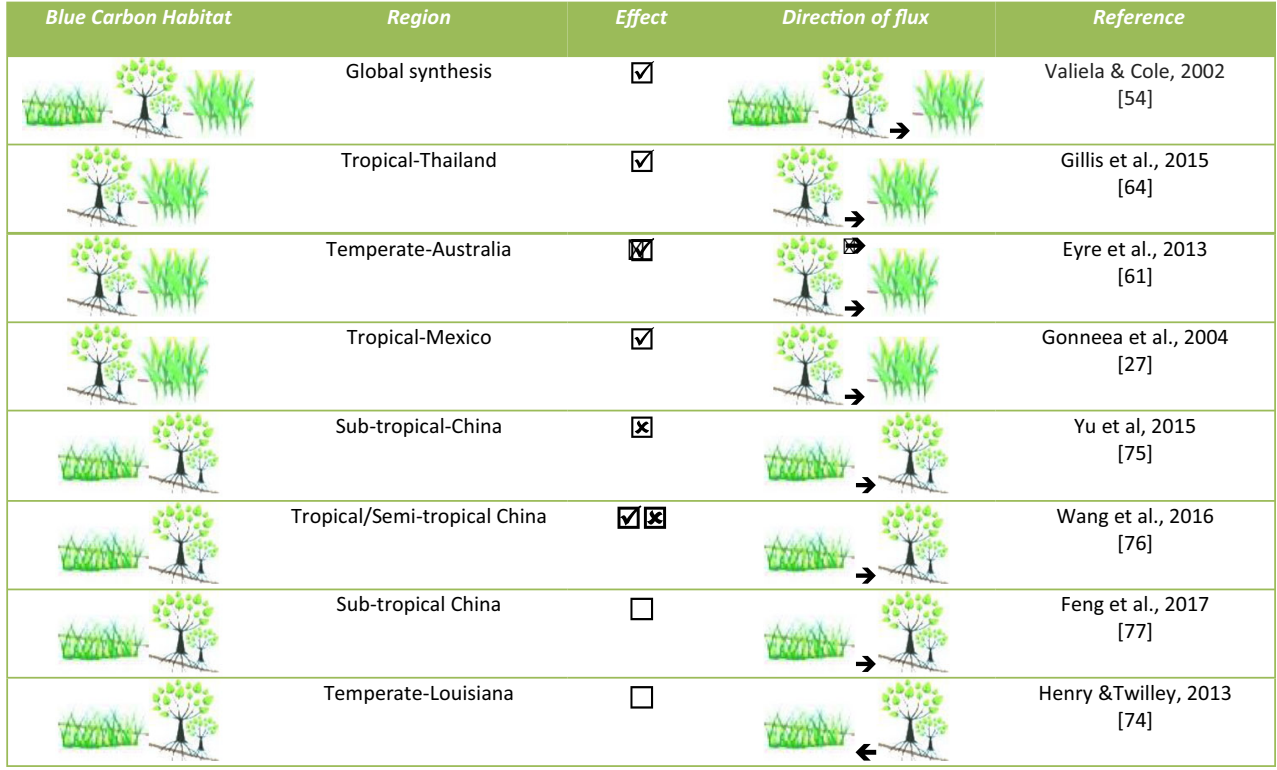

Protection of Seagrasses From Excessive Nitrogen Both mangroves and tidal marshes can act to buffer adjacent seagrasses from the effects of excessive nitrogen coming from the land, by enhancing denitrification and the burial of nitrogen in sediment [62]. Valiela and Cole reviewed the literature on seagrass coverage and persistence in coastal areas exposed to nitrogen run-off and looked for comparative evidence that the presence of adjacent tidal marsh or mangroves mitigated the impacts of this nitrogen on the seagrass [52]. Using 15 sites from which historical data on coverage was available, they found complete loss of seagrass where nitrogen loads exceeded $\sim 100 \mathrm{~kg} \mathrm{~N} \mathrm{ha}^{-1}$ year $^{-1}$, consistent with other studies that show the sensitivity of seagrass to nitrogen. However, this vulnerability was reduced in the presence of tidal marsh or mangrove, with a significant negative correlation between the area of seagrass lost and the area of wetland (i.e. mangrove or tidal marsh) near-by, measured as a percentage of the total estuary area. In addition, the productivity of the seagrass, as a percentage of total productivity in the estuary (including phytoplankton and algae) increased with the presence of marshes and mangroves. Hence landward wetland habitat can protect and enhance carbon storage in seagrasses under conditions of nitrogen stress. This is because seagrass loss will result in the loss of some or all buried carbon [63], along with the potential for future sequestration. In addition, the reduction in the proportion of total productivity coming from seagrass, as opposed to plankton, suggests that sequestration potential is reduced, since seagrass carbon is more refractory and more likely to be buried than carbon derived from plankton. These protective effects of landward marshes or mangroves decline once inputs of nitrogen exceed 20-100 kg ha ${ }^{-1}$ year $^{-1}$ [52].

Inwelling of Seagrass Nutrients Supporting Mangrove Productivity In settings where nutrients flowing from land are limited, inwelling of $\mathrm{N}$ and $\mathrm{P}$ from seagrass may support the persistence and productivity of landward systems. For example, positive correlations between the density of mangrove saplings, tree productivity and survival and carbon sequestration recorded in Sri Lanka were driven by enhanced trapping of nutrient-rich sediments inwelling from seagrass areas [39]. Arid mangrove forests in the Arabian gulf may rely on nutrient subsidies from seagrass in order to grow and persist [33].

\section{Trophic Cascades}

Excessive herbivory and bioturbation can damage or even destroy coastal vegetated habitats, leading to the release of stored carbon and loss of future sequestration potential. For example, intense grazing by moving 'fronts' of herbivorous snails was implicated in large-scale die-offs of US tidal marshes [64]. Urchins and other grazers can remove all seagrass fronds and establish 'halos' of un-vegetated areas around reefs where they live at high densities [65]. Topdown effects and controls in mangroves are less well documented; indeed, there is a long-standing suggestion that mangroves experience less intense herbivory than terrestrial forests [6]. However, this may reflect the routine use of standing-leaf damage assessments, that under-estimate folivory by missing the total consumption of leaves; when this was tracked by Burrows, he found rates of up to 29.5\% damage in Avicennia marina trees [66]. The potential for such top-down damage in blue carbon habitats suggests that trophic cascades, in which predators control the numbers or activities of herbivores or bioturbators, could help enhance and maintain carbon storage within them [67]. Such cascades are relevant to the current review if they are enabled or supported by the presence of neighbouring blue carbon habitats. Atwood et al. provide references to studies that document 'overgrazing, defoliation and 
extreme bioturbation events' in 33 blue carbon habitats; 14 seagrass, 14 tidal marsh and 5 mangroves [67]. None of these include organisms that, to our knowledge, are predominately facilitated or suppressed by interactions with neighbouring blue carbon habitats. For example, ten of the instances given for seagrass habitats involve urchins, dugongs or turtles; none of which are controlled by predators from mangroves or tidal marshes. There is however abundant evidence for movement of predators between blue carbon habitats and for the enhancement of predator biomass by the close associations between habitats. For example, pinfish (Lagodon rhomboids) were found to be more than twice as abundant in tidal marshes next to seagrass meadows than in marshes adjacent to unvegetated habitat [68]. Most species of predatory fish found in the creeks of a tropical mangrove fed in, and derived much of their energy from, the adjacent seagrass system [69]. Hence seagrass habitat supports predator biomass in the adjacent mangrove. The general ecological interconnectivity of mangrove habitats with seagrass and corals offshore in East Africa is demonstrated by the high total economic value of mangrove-dependent fish, which represent $39 \%$ of the total value of the offshore catch [70]. So, trophic cascades in one blue carbon habitat that are supported by contiguous blue carbon ecosystems are likely, but are yet to be documented in the literature.

\section{Effects of Habitat Shifts Between Blue Carbon Ecosystems on Carbon Storage}

Under most circumstances, expansion of blue carbon species into un-vegetated habitat will result in greater carbon capture and storage. But what happens when one blue carbon habitat transitions to another? This question is most relevant for the mangrove-tidal marsh interface, which is undergoing rapid alteration at many locations, driven by changes to climate and nutrient status [71]. At sub-tropical locations that have traditionally represented the latitudinal limit for mangroves, they are encroaching into tidal marsh. The effect on aboveground carbon storage is obvious, given the much higher biomass of mangrove trees compared with marsh plants. Impacts on below-ground carbon are less predictable. Most studies, largely from Australia and the USA, show increased soil carbon stocks under mangrove encroachment [71]; although, exceptions include no apparent effects on soil carbon during 60 years of encroachment of Avicennia germinans into tidal marsh in Louisiana [72]. This dominant pattern, of mangroves enhancing carbon compared with tidal marsh, is repeated in China, where the opposite transition is occurring, with the exotic marsh grass Spartina alterniflora invading and replacing native mangrove stands, possibly because of eutrophication, which may be enhanced by the presence of the marsh grass itself enriching the soil (Fig. 2). Here, soil carbon is less in marsh than in high quality mangrove habitat [73, 74], and attempts to restore mangroves have not yet succeeded in returning carbon stocks to natural levels [75]. Because climate change is raising sea levels and warming the planet, the dominant transition between blue carbon habitats, recorded currently and predicted in the future, is from tidal marsh to mangrove. In their review of the impacts of this on ecosystem services, Kelleway and colleagues find evidence that as well as enhancing carbon storage, mangroves may also be more resilient to sea level rise than tidal marsh, implying longer term security for their carbon stores (at least at any given tidal height) [71]. Hence, current and predicted transitions are likely to enhance carbon storage; however, they document the loss of other ecosystem services, such as provision of bird habitat, from tidal marsh and caution that the main changes being seen and predicted at the coast are continuing loss of all blue carbon habitats rather than changes in their relative proportions.

\section{Conclusions}

If we focus only on the mangrove trees, do we miss the wood? Well, that depends on what we are looking for. Defined functionally (and specifically, in terms of carbon capture and storage), the boundaries of a mangrove forest and the other blue carbon habitats are fuzzy. These ecosystems can influence stocks and flows of carbon hundreds of kilometres away. In addition, the sustained ability of a blue carbon ecosystem to capture and store carbon in situ depends - often critically, sometimes marginally - on its place in the seascape. The movement of water is vital in delimiting the fundamental niches, and in determining the ecological functions, of foundational coastal vegetation such as mangrove trees. It follows that evidence for physical effects of vegetation on water movement influencing the persistence and expansion of habitats elsewhere should be strong, and this is supported by our review. Where blue carbon habitats co-occur in settings with relatively high levels of water movement, we should expect that removal of one will influence the other(s), and this is particularly so for the wave-damping function of seagrass protecting inshore habitat. There is also strong evidence for the protection of seagrass meadows from excessive nutrients (and to a lesser extent sediment) by inshore habitats, especially mangroves. Whilst outwelling of carbon from mangroves and seagrass is well documented and the trapping of this carbon in adjacent blue carbon habitats has been recorded, the impact of these carbon exchanges on the total carbon storage (at the seascape level) has barely been explored. Similarly, arguments for trophic cascades, mediated by adjacent habitat, that help to control over-grazing and bioturbation are credible, but there is little current empirical evidence. It is clear that our general understanding of carbon storage at the seascape scale, and over appropriately long time-scales, is at an early stage. Improving it will require both more (from suitable case studies) and different (operating at bigger scales with new 
techniques) research. Waiting for this understanding to emerge is not a sensible management policy. The case for protecting and enhancing blue carbon habitats, as part of climate change mitigation, is a compelling one. The argument that these habitats act together to sustain and enhance their collective capacity to trap and store carbon is well supported in many cases and is at least plausible in most others. There are few examples of interactions between these habitats resulting in negative impacts on carbon storage. Ignoring the seascape when considering blue carbon will risk missing the wood-and the marsh and the seagrass - for the trees.

Acknowledgements Our thanks go to Sarah Murray for her help with Fig. 1 and Martin Dahl for comments on carbon exchange between blue carbon habitats. The manuscript was improved with helpful comments from a reviewer.

\section{Compliance with Ethical Standards}

Conflict of Interest The authors declare that they have no conflict of interest.

Human and Animal Rights Statement All reported studies/experiments with human or animal subjects performed by the authors have been previously published and complied with all applicable ethical standards (including the Helsinki declaration and its amendments, institutional/ national research committee standards and international/national/institutional guidelines).

Open Access This article is distributed under the terms of the Creative Commons Attribution 4.0 International License (http:// creativecommons.org/licenses/by/4.0/), which permits unrestricted use, distribution, and reproduction in any medium, provided you give appropriate credit to the original author(s) and the source, provide a link to the Creative Commons license, and indicate if changes were made.

\section{References}

Papers of particular interest, published recently, have been highlighted as:

- Of importance

•- Of major importance

1. Duarte CM, Losada IJ, Hendriks IE, Mazarrasa I, Marbà N. The role of coastal plant communities for climate change mitigation and adaptation. Nat Clim Chang. 2013;3:961-8. https://doi.org/10. 1038/nclimate1970. A useful overview of the emerging science and its relevance for policy.

2. Chen G, Chen B, Yu D, Tam NFY, Ye Y, Chen S (2016) Soil greenhouse gas emissions reduce the contribution of mangrove plants to the atmospheric cooling effect. Environ Res Lett 11 https://doi.org/10.1088/1748-9326/11/12/124019.

3. Mcleod E, Chmura GL, Bouillon S, Salm R, Björk M, Duarte CM, et al. A blueprint for blue carbon: toward an improved understanding of the role of vegetated coastal habitats in sequestering $\mathrm{CO} 2$. Front Ecol Environ. 2011;9:552-60.
4. Mumby PJ, Hastings A. The impact of ecosystem connectivity on coral reef resilience. J Appl Ecol. 2007;45:854-62.

5. Pittman SJ, Caldow C, Hile SD, Monaco ME. Using seascape types to explain the spatial patterns of fish in the mangroves of SW Puerto Rico. Mar Ecol Prog Ser. 2007;348:273-84.

6. Alongi DM. The energetics of mangrove forests. Dordrecht: Springer Netherlands; 2009.

7. Duarte CM, Chiscano CL. Seagrass biomass and production: a reassessment. Aquat Bot. 1999;65:159-74.

8. Kennedy H, Beggins J, Duarte CM, Fourqurean JW, Holmer M, Marbá N, et al. Seagrass sediments as a global carbon sink: isotopic constraints. Glob Biogeochem Cycles. 2010;24:1-8.

9. Krauss KW, Mckee KL, Lovelock CE, Cahoon DR, Saintilan N, Reef R, et al. How mangrove forests adjust to rising sea level. New Phytol. 2014;202:19-34. Responses to sea level rise will be critical in determining long term carbon storage. This paper reviews some of the important progress in our understanding of this in mangove forests over the past two decades.

10. Pendleton L, Donato DC, Murray BC, Crooks S, Jenkins WA, Sifleet $\mathrm{S}$, et al. Estimating global "blue carbon" emissions from conversion and degradation of vegetated coastal ecosystems. PLoS One. 2012;7:e43542. https://doi.org/10.1371/journal.pone. 0043542.

11. Lovelock CE, Atwood T, Baldock J, Duarte CM, Hickey S, Lavery PS, et al. Assessing the risk of carbon dioxide emissions from blue carbon ecosystems. Front Ecol Environ. 2017;15:257-65.

12.• Gillis L, Bouma T, Jones C, van Katwijk M, Nagelkerken I, Jeuken C, et al. Potential for landscape-scale positive interactions among tropical marine ecosystems. Mar Ecol Prog Ser. 2014;503:289-303. With a similar focus as the current paper, but including coral reefs and considering all positive interactions rather than only on carbon, this work gives useful quantitative estimates for some of the effects.

13. Teal JM. Energy flow in the salt marsh ecosystem of Georgia. Ecology. 1962;43:614-24.

14. Odum E. (1968) A research challenge: evaluating the productivity of coastal and estuarine water. Second sea grant Conf.

15. Odum WE, Heald EJ. Mangrove forests and aquatic productivity. In: Hasler AD, editor. Coupling L. water Syst. Berlin: SpringerVerlag; 1975. p. 129-36.

16. Bouillon S, Connolly RM. Carbon exchange among tropical coastal ecosystems. Ecol Connect among Trop Coast Ecosyst. 2009:45-70.

17. Bouillon S, Borges AV, Castañeda-Moya E, et al. Mangrove production and carbon sinks: a revision of global budget estimates. Global Biogeochem Cycles. 2008;22:n/a-n/a.

18. Maher DT, Santos IR, Gleeson J, Eyre BD (2013) Groundwaterderived dissolved inorganic and organic carbon exports from a mangrove tidal creek: the missing mangrove carbon sink? 58: 475-488.

19. Adame MF, Lovelock CE. Carbon and nutrient exchange of mangrove forests with the coastal ocean. Hydrobiologia. 2011;663:2350 .

20. Hemminga M, Slim F, Kazungu J, Ganssen G, Nieuwenhuize J, Kruyt N. Carbon outwelling from a mangrove forest with adjacent seagrass beds and coral reefs (Gazi Bay, Kenya). Mar Ecol Prog Ser. 1994;106:291-301.

21. Chen G, Azkab MH, Chmura GL, Chen S, Sastrosuwondo P, Ma Z, et al. Mangroves as a major source of soil carbon storage in adjacent seagrass meadows. Sci Rep. 2017;7:42406.

22. Agawin NSR, Duarte CM. Evidence of direct particle trapping by a tropical seagrass meadow. Estuaries. 2002;25:1205-9.

23. Bos AR, Bouma TJ, de Kort GLJ, van Katwijk MM. Ecosystem engineering by annual intertidal seagrass beds: sediment accretion and modification. Estuar Coast Shelf Sci. 2007;74:344-8. 
24. Potouroglou M, Bull JC, Krauss KW, Kennedy HA, Fusi M, Daffonchio D, et al. Measuring the role of seagrasses in regulating sediment surface elevation. Sci Rep. 2017:1-11.

25. Kennedy H, Gacia E, Kennedy DP, Papadimitriou S, Duarte CM. Organic carbon sources to SE Asian coastal sediments. Estuar Coast Shelf Sci. 2004;60:59-68.

26. Gonneea ME, Paytan A, Herrera-Silveira JA. Tracing organic matter sources and carbon burial in mangrove sediments over the past 160 years. Estuar Coast Shelf Sci. 2004;61:211-27.

27. Gullström M, Lyimo LD, Dahl M, et al. Blue carbon storage in tropical seagrass meadows relates to carbonate stock dynamics, plant-sediment processes, and landscape context: insights from the western Indian Ocean. Ecosystems. 2017:1-16. This paper is one of the first to attempt a seascape approach in understanding carbon stocks.

28. Van de Broek M, Vandendriessche C, Poppelmonde D, Merckx R, Temmerman S, Govers G (2018) Long-term organic carbon sequestration in tidal marsh sediments is dominated by old-aged allochthonous inputs in a macro-tidal estuary. Glob Chang Biol 1-15.

29. Duarte CM, Cebrián J. The fate of marine autotrophic production. Limnol Oceanogr. 1996;41:1758-66.

30. Tzortziou M, Neale PJ, Megonigal JP, Lee Pow C, Butterworth M. Spatial gradients in dissolved carbon due to tidal marsh outwelling into a Chesapeake Bay estuary. Mar Ecol Prog Ser. 2011;426:4156.

31. Guest MA, Connolly RM, Lee SY, Loneragan NR, Breitfuss MJ. Mechanism for the small-scale movement of carbon among estuarine habitats: organic matter transfer not crab movement. Oecologia. 2006;148:88-96.

32. Duarte CM, Krause-Jensen D. Export from Seagrass meadows contributes to marine carbon sequestration. Front Mar Sci. 2017;4:1-7. This demonstrates just how far carbon exports might travel from seagrass systems.

33. Walton MEM, Al-Maslamani I, Skov MW, Al-Shaikh I, Al-Ansari IS, Kennedy HA, et al. Outwelling from arid mangrove systems is sustained by inwelling of seagrass productivity. Mar Ecol Prog Ser. 2014;507:125-37.

34. Mcivor A, Spencer T, Möller I. Storm surge reduction by mangroves. Natural Coastal Protection Series: Report. 2012;2

35. Guannel G, Arkema K, Ruggiero P, Verutes G. The power of three: coral reefs, seagrasses and mangroves protect coastal regions and increase their resilience. PLoS One. 2016;11:1-22. An illustration of how modelling approaches might help illuminate seascape effects.

36. Balke T, Bouma TJ, Horstman EM, Webb EL, Erftemeijer PLA, Herman PMJ. Windows of opportunity: thresholds to mangrove seedling establishment on tidal flats. Mar Ecol Prog Ser. 2011;440:1-9.

37. Kirui BYK, Huxham M, Kairo J, Skov M. Influence of species richness and environmental context on early survival of replanted mangroves at Gazi bay, Kenya. Hydrobiologia. 2008;603:171-81.

38. Ondiviela B, Losada IJ, Lara JL, Maza M, Galván C, Bouma TJ, et al. The role of seagrasses in coastal protection in a changing climate. Coast Eng. 2014;87:158-68.

39. Kumara MP, Jayatissa LP, Krauss KW, Phillips DH, Huxham M. High mangrove density enhances surface accretion, surface elevation change, and tree survival in coastal areas susceptible to sealevel rise. Oecologia. 2010;164:545-53.

40. Kitheka JU, Ongwenyi GS, Mavuti KM. Dynamics of suspended sediment exchange and transport in a degraded Mangrove Creek in Kenya. Ambio. 2002;31:580-7.

41. Freeman AS, Short FT, Isnain I, Razak FA, Coles RG. Seagrass on the edge: land-use practices threaten coastal seagrass communities in Sabah, Malaysia. Biol Conserv. 2008;141:2993-3005.

42. Conrad SR, Santos IR, Brown DR, Sanders LM, van Santen ML, Sanders CJ. Mangrove sediments reveal records of development during the previous century (Coffs Creek estuary, Australia). Mar Pollut Bull. 2017;122:441-5.

43. Alegria H, Martinez-Colon M, Birgul A, Brooks G, Hanson L, Kurt-Karakus P. Historical sediment record and levels of PCBs in sediments and mangroves of Jobos Bay, Puerto Rico. Sci Total Environ. 2016;573:1003-9.

44. Hayden HL, Granek EF. Coastal sediment elevation change following anthropogenic mangrove clearing. Estuar Coast Shelf Sci. 2015;165:70-4

45. Stokes DJ, Harris RJ. Sediment properties and surface erodibility following a large-scale mangrove (Avicennia marina) removal. Cont Shelf Res. 2015;107:1-10.

46. Ellegaard M, Nguyen NTG, Andersen TJ, Michelsen A, Nguyen NL, Doan NH, et al. Temporal changes in physical, chemical and biological sediment parameters in a tropical estuary after mangrove deforestation. Estuar Coast Shelf Sci. 2014;142:32-40.

47. Koshiba S, Besebes M, Soaladaob K, Isechal AL, Victor S, Golbuu Y. Palau's taro fields and mangroves protect the coral reefs by trapping eroded fine sediment. Wetl Ecol Manag. 2013;21:157-64.

48. Elser JJ, Bracken MES, Cleland EE, Gruner DS, Harpole WS, Hillebrand $\mathrm{H}$, et al. Global analysis of nitrogen and phosphorus limitation of primary producers in freshwater, marine and terrestrial ecosystems. Ecol Lett. 2007;10:1135-42.

49. Dise NB, Ashmore M, Belyazid S, Bleeker A, Bobbink R, Vries W (2011) Nitrogen as a threat to European terrestrial biodiversity. In: Sutton MA, Howard CM, Erisman JW, Billen G, Bleeker A, Grennfelt P, van Grinsven H, Grizzetti B (eds) Eur. Nitrogen Assess. Cambridge University Press, Cambridge, pp 463-494.

50. Lovelock CE, Ball MC, Martin KC, Feller CI. Nutrient enrichment increases mortality of mangroves. PLoS One. 2009;4:e5600.

51. Bertness MD, Ewanchuk PJ, Silliman BR. Anthropogenic modification of New England salt marsh landscapes. Proc Natl Acad Sci. 2002;99:1395-8.

52. Valiela I, Cole ML. Comparative evidence that salt marshes and mangroves may protect seagrass meadows from land-derived nitrogen loads. Ecosystems. 2002;5:92-102.

53. Duarte CM, Marba N, Santos R (2000) What may cause loss of seagrasses? In: Borum J, Duarte CM, Krause-Jensen D, Greve TM (eds) Eur. seagrasses an Introd. to Monit. Manag. The M\&MS project, pp 24-32.

54. Burkholder JM, Tomasko DA, Touchette BW. Seagrasses and eutrophication. J Exp Mar Bio Ecol. 2007;350:46-72.

55. Jefferies RL, Perkins N. The effects on the vegetation of the additions of inorganic nutrients to salt marsh soils at Stiffkey, Norfolk. J Ecol. 1977;65:867.

56. Thornton PE, Lamarque J-F, Rosenbloom NA, Mahowald NM. Influence of carbon-nitrogen cycle coupling on land model response to CO 2 fertilization and climate variability. Global Biogeochem Cycles. 2007;21:n/a-n/a.

57. Zaehle S, Friedlingstein P, Friend AD. Terrestrial nitrogen feedbacks may accelerate future climate change. Geophys Res Lett. 2010;37:n/a-n/a.

58. Gerber S, Hedin LO, Oppenheimer M, Pacala SW, Shevliakova E. Nitrogen cycling and feedbacks in a global dynamic land model. Global Biogeochem Cycles. 2010;24:n/a-n/a.

59. Eyre BD, Maher DT, Squire P. Quantity and quality of organic matter (detritus) drives $\mathrm{N} 2$ effluxes (net denitrification) across seasons, benthic habitats, and estuaries. Glob Biogeochem Cycles. 2013;27:1083-95.

60. Quinn Thomas R, Canham CD, Weathers KC, Goodale CL. Increased tree carbon storage in response to nitrogen deposition in the US. Nat Geosci. 2010;3:13-7.

61. Sanders CJ, Eyre BD, Santos IR, Machado W, Luiz-Silva W, Smoak JM, et al. Elevated rates of organic carbon, nitrogen, and phosphorus accumulation in a highly impacted mangrove wetland. Geophys Res Lett. 2014;41:2475-80. 
62. Gillis LG, Bouma TJ, Cathalot C, Ziegler AD, Herman PM. Particulate matter in mangrove forests and seagrass beds as a nitrogen source in tropical coastal ecosystems. Biotropica. 2015;47: 286-91.

63. Macreadie PI, Trevathan-Tackett SM, Skilbeck CG, Sanderman J, Curlevski N, Jacobsen G, et al. Losses and recovery of organic carbon from a seagrass ecosystem following disturbance. Proceedings Biol Sci. 2015;282:20151537.

64. Silliman BR, van de Koppel J, Bertness MD, Stanton LE, Mendelssohn IA (7547BC) Drought, snails, and large-scale dieoff of Southern U. S. salt marshes Author ( s ): Brian R. Silliman, Johan van de Koppel, mark D. Bertness, lee E. Stanton, Irving A. Source : Science, New Series, Vol. 310, no. 5755 ( Dec. 16, 2005 ). Science (80- ) 310:1803-1806, 2005.

65. Heck KL, Valentine JF. Plant-herbivore interactions in seagrass meadows. J Exp Mar Bio Ecol. 2006;330:420-36.

66. Burrows DW (2003) The role of insect leaf herbivory on the mangroves Avicennia marina and Rhizophora stylosa. James Cook University.

67. Atwood TB, Connolly RM, Ritchie EG, Lovelock CE, Heithaus MR, Hays GC, et al. Predators help protect carbon stocks in blue carbon ecosystems. Nat Clim Chang. 2015;5:1038-45.

68. Irlandi EA, Crawford MK. Habitat linkages: the effect of intertidal saltmarshes and adjacent subtidal habitats on abundance, movement, and growth of an estuarine fish. Oecologia. 1997;110:222-30.

69. Marguillier S, van der Velde G, Dehairs F, Hemminga MA, Rajagopal S. Trophic relationships in an interlinked mangrove- seagrass ecosystem as traced by $\mathrm{C} 13$ and N15. Mar Ecol Prog Ser. 1997;151:115-21.

70. Huxham M, Emerton L, Kairo J, Munyi F, Abdirizak H, Muriuki T, et al. Applying climate compatible development and economic valuation to coastal management: a case study of Kenya's mangrove forests. J Environ Manag. 2015;157:168-81.

71. Kelleway JJ, Cavanaugh K, Rogers K, Feller IC, Ens E, Doughty C, et al. Review of the ecosystem service implications of mangrove encroachment into salt marshes. Glob Chang Biol. 2017;23:3967-83.

72. Henry KM, Twilley RR. Soil development in a coastal Louisiana wetland during a climate-induced vegetation shift from salt marsh to mangrove. J Coast Res. 2013;292:1273-83.

73. Yu X, Yang J, Liu L, Tian Y, Yu Z. Effects of Spartina alterniflora invasion on biogenic elements in a subtropical coastal mangrove wetland. Environ Sci Pollut Res. 2015;22:3107-15.

74. Wang D, Huang W, Liang R, Li F. Effects of Spartina alterniflora invasion on soil quality in coastal wetland of Beibu gulf of South China. PLoS One. 2016;11:e0168951.

75. Feng J, Zhou J, Wang L, Cui X, Ning C, Wu H, Zhu X, Lin G (2017) Effects of short-term invasion of Spartina alterniflora and the subsequent restoration of native mangroves on the soil organic carbon, nitrogen and phosphorus stock. https://doi.org/10.1016/j. chemosphere.2017.06.060.

76. Dobson M, Frid C. Ecology of aquatic systems. Oxford: Oxford University Press; 2008.

77. Bouillon S (2004) Interactive comment on " carbon sources supporting benthic mineralization in mangrove and adjacent seagrass sediments ( Gazi Bay, Kenya )" by S. Bouillon et al. 